DOI: $10.18276 /$ ais.2019.27-17

\title{
Michał Kasiński
}

\section{RELIGIOUS INSTRUCTION IN POLISH PUBLIC SCHOOLS IN LIGHT OF UNIVERSAL AND EUROPEAN STANDARDS}

\begin{abstract}
The study is devoted to the analysis of legal regulations at a national level (Poland), the jurisprudence (case-law) of the Constitutional Tribunal and the practices of central and local government in matters related to public education, as perceived from the point of view of universal and European standards protecting freedom of conscience and religion.

The author justifies the claim that the standards set by the Polish Constitutional Tribunal in this field are fundamentally different from the standards established in the case-law of the UN Human Rights Committee and the European Court of Human Rights.

This leads to tolerance of repeated violation of the principle of ideological impartiality of public authorities. The principle, declared in Article 25 (2) of the Constitution of the Republic of Poland ${ }^{1}$, is violated both by state-level legislation pertaining to the sphere of religion, and by biased practices of educational administration.

What is particularly abnormal is the inertia of public authorities that are obliged to supervise religious education and/or instruction, and their indifference to the unlawful activities of the entity interested in ideological domination over the education sector.
\end{abstract}

* dr hab. Michał Kasiński, Professor of the PUSB (State College of Applied Sciences in Skierniewice), Professor of the University of Lodz, email address: mikasin@tlen.pl. ORCID: 0000-0002-6999-7502

1 Act of 2 April 1997 Constitution of the Republic of Poland, Dz. U. (Journal of Laws) of 1997 No. 78, item 483, as amended. 
The author expresses the conviction that a fundamental change of the approach of the Polish legislator should take place, especially as regards the role and tasks of state entities in protecting freedom of conscience and religion in the educational activities of public schools. This would guarantee the philosophical and religious neutrality of education in state schools.

Keywords: religious education, public education, freedom of conscience and religion, ideological neutrality of public authorities, UN Human Rights Committee, European Court of Human Rights

1. International and European acts which proclaim protection of freedom of conscience and belief, neither forbid nor include obligation of providing Religious Education (in a broad sense: teaching about religion in general; in a narrow sense: teaching of a particular religion; the Polish context tends to employ the narrow sense in a vast majority of cases; that is why "religious education" and "religious instruction" are used interchangeably) in public, or state schools. Their provisions oblige countries to recognize the right of parents to bring their children up and teach them in accordance with their own religious and philosophical beliefs. ${ }^{2}$ In particular, provisions of two fundamental documents of the United Nations of 1966: Article 18(4) of the International Covenant on Civil and Political Rights ${ }^{3}$ and Article 13(3) of the International Covenant on Economic, Social and Cultural Rights ${ }^{4}$ include obligation of State-Parties to each covenant, to respect the freedom of parents in providing their children with religious and moral education in accordance with their own beliefs. Report No. 1 to European Convention on Human Rights of 1950, indicates in Article 2 the parents' right to have their own rights to provide their children with education in accordance with their personal religious and philosophical beliefs respected by the State which performs its obligations in education. ${ }^{5} \mathrm{~A}$ similar provision is included in Principle VII of the Final Act of the Conference on Security and Co-operation in

2 Sobczak, W., Wolność myśli, sumienia i religii. Poszukiwanie standardu europejskiego, Toruń 2013, pp. 440-458.

3 UN General Assembly, International Covenant on Civil and Political Rights, 16 December 1966, United Nations, Treaty Series, vol. 999, p. 171.

4 UN General Assembly, International Covenant on Economic, Social and Cultural Rights, 16 December 1966, United Nations, Treaty Series, vol. 993, p. 3.

5 Council of Europe, European Convention for the Protection of Human Rights and Fundamental Freedoms, as amended by Protocols Nos. 11 and 14, 4 November 1950, ETS 5. 
Europe of $1975^{6}$. In accordance with Article 14(3) of the Charter of Fundamental Rights of the European Union of 2007 the right of parents to provide children with education in accordance with their own religious, philosophical and pedagogical beliefs, is respected, in accordance with state acts governing the exercise of this right. ${ }^{7}$

In light of the mentioned acts, the right in question is of neutral nature and is firstly executed in a family entitled to organize their religious or irreligious life freely at home under the parents' direction. Parents are entitled to decide whether their children should receive religious education and what form it should take, in accordance with their own religious beliefs and even with their general outlook on life. What is more, Article 14 of the UN Convention on the Rights of the Child of 1989 includes an obligation for Party States to respect children's right to freedom of thought, conscience and belief, and to respect the rights and obligations of parents (legal guardians) concerning directing their child in terms of exercising its rights in a manner consistent with developing abilities of the child. ${ }^{8}$ All these regulations should function to protect the family (which is the subject of freedom of conscience and belief) against arbitrary inference of government authorities, hence it is difficult to find there any indications concerning e.g. methods of resolving disputes between parents of different beliefs in terms of the religious direction of bringing up their children.

2. Real problems of protection of child's freedom of conscience and belief in the education process occur not only in the area of relations inside the family, but mainly in relations between children/students and their parents and the authorities of the school that the particular students attend. In this regard, two kinds of solutions may be identified, stated in acts of international and European law which should guarantee parents' influence on the direction of religious education at schools. Firstly, ensuring the freedom of establishing private schools whose curriculums include (or do not include) religious education and providing the

6 Organization for Security and Co-operation in Europe (OSCE), Conference on Security and Co-operation in Europe (CSCE): Final Act of Helsinki, 1 August 1975.

7 European Union, Charter of Fundamental Rights of the European Union, OJ C 326, 26.10.2012, pp. 391-407.

8 The document ratifying this convention by the Republic of Poland was supplemented with a declaration on the basis of which a child should execute (inter alia) the right in question with respect of parental authority, and in accordance with Polish customs and traditions concerning the position of the child in the family and outside it. Act of 20 November 1989 on ratifying the UN Convention on the Rights of the Child, Dz.U. (Journal of Laws) of 1991 No.120, item 526, as amended). 
child with freedom of choice of such a school which is run e.g. by a particular religious or non-religious association. Secondly, acceptance of admissibility of introduction of religious contents in public school curriculum and delivering them in a didactic process to all students or only to those students whose parents (or the students alone) expressed such a will by attending separate classes devoted to a given religion. In this way, the original right of parents to bring their children up in accordance with their own beliefs, takes the form of the right to teach children a particular religion in a private school (first option) or in a public school as well (option two). It is clear that the classes are to be conducted only by a duly qualified teacher who is also accepted by a relevant religious association. The second option which introduces religious education also in public schools is definitely more significant in European states because of the principle of the universal right to education and compulsoriness (and gratuitousness) of education at least at the basic level which is respected there (Article 26(1) of the Universal Declaration of Human Rights, Article 13 of the International Covenant on Economic, Social and Cultural Rights, Article 14 of the Charter of Fundamental Rights of the European Union, Article 28 of the Convention on the Rights of the Child).

It is the public school system that is directed and supervised by governmental or local authorities where the principles of universality and compulsoriness of education are implemented. Activity of such schools, in the area of interest of this paper, is subject to legal and political principles which govern relations between religious associations and the state. In confessional states there are reasons for including religious content in school curriculum which is consistent with the doctrine of the governing church, and even for introducing obligation of teaching the faith of a particular church. In states that represent separation of church and state or, in a less radical option, a neutral outlook on governmental authorities, there are reasons for providing secular schools.

In Europe, there is a constant tendency of shifting from the model of a confessional state towards various options of democratic secular state of law, or a lay state. ${ }^{9}$ In some of the states certain legal solutions are still preserved, which guarantees preference for religious associations (especially for the dominant confession) in various spheres of public life, also in public education. This preference faces more or less justified claims of its inconsistency with the prin-

9 Pietrzak, M., Państwo laickie, "Przegląd Humanistyczny" 1990, No. 8-9, reprint: Pietrzak, M., Demokratyczne, świeckie państwo prawne, Warszawa 1999, see especially pp. 140-143. 
ciple of protection of freedom of conscience and belief. On the other hand, too strict an understanding of secular education is also subject of criticism. It may be argued that a total exclusion of religious instruction from public school curriculum would, in fact, mean opening a way for atheist indoctrination, which would be inconsistent with the rights of students (and their parents) to have an influence on the direction of education consistent with their religious beliefs and, in consequence, it would mean weakening of freedom of conscience and belief. Having started at this point, a conclusion may be formed that religious instruction is "a remarkable achievement of the European legal culture in terms of respecting freedom of conscience and religion, as this means protection of the parent's religious freedom, in the scope of raising children according to the parents' views within public education"10.

An attempt to form a compromise between the two contradictory tendencies is visible in acts of international law. Following Article 2 of the First Protocol to the Convention for the Protection of Human Rights and Fundamental Freedoms, "No person shall be denied the right to education. In the exercise of any functions which it assumes in relation to education and to teaching, the State shall respect the right of parents to ensure such education and teaching in conformity with their own religious and philosophical convictions". As both the academic writing and judicial decisions pointed out, this provision does not guarantee the absolute right to education of children in accordance with the beliefs of parents, but merely "respect" towards them. This "respect towards parent's beliefs" can be understood in a number of ways, but it certainly assumes the existence of negative obligations on the part of the State, as well as certain positive obligations. ${ }^{11}$

The controversial nature of state law regulations in the area in question is the reason for numerous complaints against Party States to the conventions mentioned above, chiefly addressed to the United Nations Human Rights Committee (hereinafter referred to as: HRC) and European Court of Human Rights (hereinafter referred to as: ECtHR). The case-law of these bodies includes more or less conservative attempts to define transnational (universal, European) standards in teaching religion as part of public education. It would be valuable to determine

$10 \quad$ Nauczanie religii w polskiej szkole, 10.01.2019, https://ekai.pl/nauczanie-religii-w-polskiej-szkole-2/, accessed on: 28.11.2019; especially quote of Father Józef Krukowski.

11 Nowicki, M.A., Wokót Konwencji Europejskiej. Komentarz do Europejskiej Konwencji Praw Człowieka, Warszawa 2017, p. 882; ECtHR, Lautsi and others v. Italy, Application No. 30814/06, Grand Chamber, 18 March 2011, par. 61. 
the degree to which these standards have influenced the making and application of provisions of Polish law with regard to teaching religion in public schools.

Special attention should be paid to the standard of ensuring freedom of conscience and belief which was shaped by the judicial decisions of the United Nations Human Rights Committee and the European Court of Human Rights, under which the parents are granted the right to decide about religious education of their children with respect to their education in a public school. According to the established practice of the Human Rights Committee, teaching religion at public schools is acceptable if the parents are granted the right to exempt, fully and freely, their children from such classes. Alternative classes in ethics or in history of religion are to be held in a neutral manner. ${ }^{12}$

The European Court of Human Rights has taken the view that, while religious education at school is not contrary to the Convention, it is required to check in detail whether it involves the obligation to involve students in some form of religious practice or to expose them in any form to religious indoctrination. What is important at this stage is the possibility of exempting a student from such lessons. Parents may not send their children to be instructed in a religion that they do not like. Religious education should be held in a way allowing a real possibility of making such a choice. ${ }^{13}$

4. Religious education in Poland is currently regulated by provisions of the Constitution of 2 April 1997, the already mentioned conventions to which the Republic of Poland is a party, the Concordat between the Holy See and Poland of 28 July $1993^{14}$, the Act on guarantees of freedom of conscience and belief of 17 May $1989^{15}$ and other acts on confessions ${ }^{16}$, the Act on the education system

12 Wieruszewski, R., Nauczanie religii w szkołach publicznych oraz finansowanie szkót religijnych w świetle orzecznictwa Komitetu Praw Człowieka ONZ, in: Wieruszewski, R., Wyrzykowski, M., Kondratiewa-Bryzik, L. (eds.), Prawne granice wolności sumienia $i$ wyznania, Warszawa 2012, pp. 170-173.

13 M. A. Nowicki, op. cit., p. 886; ECtHR, Angeleni v. Sweden, Application no. 1049/83, 3 December 1986, p. 41; ECtHR, Bernard v. Luxembourg, Application no. 17187/90, 8 September 1993, p. 57; ECtHR, C.J., J.J., E.J. v. Poland, Application no. 23380/94, 16 January 1996, p. 46.

14 Dz. U. (Journal of Laws) of 1998, No. 51, item 318.

15 Dz. U. (Journal of Laws) of 2017, item 1153.

16 It especially concerns the so-called individual acts regulating the attitude of the State to certain religious associations, among others the Act of 17 May 1989 on the relations of the State and the Catholic Church in the Republic of Poland, Dz. U. (Journal of Laws) of 2018, item 380, as amended) and several acts regulating the legal situation of 14 other religious associations. 
of 7 September 1991, ${ }^{17}$ Regulation of the Ministry of Education on conditions and ways of organizing religious education in public pre-schools and schools of 14 April 1992, ${ }^{18}$ and the Act on specific conditions and grading, classifying and promotion schemes for students and course participants at public schools of 10 June $2015^{19}$ and agreements of this ministry with leaderships of specific religious associations.

The first impression is that the Polish law contains regulations in line with the above-mentioned standards for religious education in public schools. In accordance with Article 53(4) of the Constitution, the religion of a church or other legally recognized religious organization may be taught in schools, but other peoples' freedom of religion and conscience shall not be infringed thereby. The Constitution does not impose an obligation on public schools to conduct religious instruction yet it does not provide for restriction of such instruction if citizens express such a wish. ${ }^{20}$ However, what remains doubtful is the constitutionality of Article 12 of the Concordat which states that "by recognizing the right of parents to the religious education of children and the principle of tolerance, the state guarantees that public primary and post-primary schools as well as kindergartens maintained by bodies of state administration and local government, provide religious education under the school and pre-school curriculum, according to the will of those interested". The phrase "the state guarantees..." may be understood literally as the state's commitment to the general introduction of religious instruction in public schools and kindergartens. It would be, however, a contra legem fundamentalem mistake. The interpretation of the provision in question, taking into account the content of the parent norm, expressed in two provisions of the Polish Constitution: "Parents have the right to ensure their children a moral and religious upbringing and teaching in accordance with their convictions" (Article 53(3) of the Constitutions) seems convincing. Upbringing should take into account the degree of maturity of a child, as well as his freedom of conscience and belief and also his convictions" (Article 48(1) of the Constitution). Moreover, the Concordat refers to the principle of tolerance and "the wishes of those involved". One

\footnotetext{
17 Dz. U. (Journal of Laws) of 2019, item 1481, as amended.

18 Dz. U. (Journal of Laws) of 1992, No. 36, item 155.

19 Dz. U. (Journal of Laws) of 2019, item 372.

20 Florczak-Wątor, M., Art.53 [Wolność sumienia i wyznania], in: Tuleja, P. (ed.), Konstytucja Rzeczypospolitej Polskiej Komentarz, Warszawa 2019, pp. 184-185.
} 
may agree with the opinion that, in this sense, the provision of Article 12(1) of the Concordat does not contradict the principle of voluntary use of religious classes, but rather supports this principle by allowing its full understanding: instruction in religious education in public schools is dependent on a positive declaration of intent to participate in religion classes. ${ }^{21}$

This statement may be made by the students' parents, their guardians or the students themselves. According to the Act on the Education System, the right to choose religious instruction in pre-schools and primary schools belongs to the parents; while in secondary schools it belongs to the parents or the students themselves. An adult student submits the statement on his/her own.

Religious instruction is optional in public pre-schools and schools. ${ }^{22}$ Polish law does not provide for the requirement of submitting a clear declaration of intent of a student's parent or the student himself/herself not to participate in religion classes, because such a practice could mean not only illegal pressure, but an outright breach of the constitutional ban of obliging anyone by the public authorities to disclose their religious convictions or belief (Article 53(7) of the Constitution). The phenomenon of violating this ban - which was widespread until recently - caused the 2013 Commissioner for Human Rights' appeal to the Minister of National Education, who undertook to provide the superintendents and school principals with information about the illegality of the practice in question..$^{23}$

The statement concerning the decision on choosing instruction in religious education should be submitted to the authorities of the school, and not to the church authorities. The school authorities are not allowed to reveal to a religious educator or the leadership of the church or any third party the identity of students who (or whose parents) have submitted an opt-out decision or who have not expressed any will. Practice in this respect often varies. It frequently occurs that the school authorities inform the religious educator or the authorities of the church about the full list of pupils - thus enabling the identification of students

${ }^{21}$ Góralski, W., Pieńdyk, A., Zasada niezależności i autonomii państwa i Kościoła w konkordacie polskim z 1993 r., Warszawa 2007, pp. 38-39.

22 Kasiński, M., Ochrona wolności sumienia i wyznania, in: Duniewska, Z. (ed.) et al., Prawo administracyjne materialne, Warszawa 2019, pp. 226-228.

23 Polish Commissioner for Human Rights, Statement of 15 November 2013, reference number RPO / 601727/08/1/104122. http:/www.sprawy-generalne.brpo.gov.pl, (downloaded 4.07.2014). This view seems to be shared by the spokesman of the Polish Bishops' Conference, cf. Statement of the EPC: Religious education not is an optional subject. Classes can take place in the middle of the school day, 18.03.2019. Gazeta.pl, accessed on: 28.11.2019. 
whose parents have not opted in or have opted out. Another dysfunctional phenomenon in this area is that fact of not submitting a statement for the child's participation in religious education classes is identified as a specified denominational or worldview option of his/her parents (e.g. incidental cases of proclamation by some ecclesiastical authorities or catechists, that the resignation from the child's attending religious instruction is, de facto, equivalent to the apostasy of his/her parents). ${ }^{24}$ Even more dangerous is the passivity of the school and public authorities towards the described negative behaviour, even if its scope seems statistically narrow. One of the reasons for this inaction may be the extremely limited legal possibilities of the application of the measures of pedagogical supervision over this behaviour. Another one involves the fear of disturbances in the relations with the ecclesiastical authorities, which often tend to view the critique of the methods and results of catechetical activities as an attack on the Church itself.

5. Ethics classes in Poland, in contrast to the solutions adopted in other countries, as well as those suggested by the jurisprudence of international courts, are not an alternative to religious instruction for two reasons. First, parents or students, have the right to choose one of these subjects or the resignation from both; it is also acceptable to take part in both the religious instruction and ethics classes. Secondly, so far the overwhelming majority of public schools do not hold classes in ethics. ${ }^{25}$ In this situation, fulfilling the requirement of the ideological neutrality of teaching ethics in Poland is not a subject of major controversy. The situation may, however, change if, for example, under pressure from European authorities, ethics classes will be organized in a greater number of schools. Then, probably the words from the preamble of the Act on the education system stating that "Teaching and upbringing-respecting the Christian value system is based on the universal principles of ethics" will take on a new tone.

6 . The material taught during the religious education classes and the principles of assessing (grading) the students are of crucial importance. The judicature

24 Suchecka, J., Kuria straszy rodziców. Wypisateś dziecko z religii? "To pisemna apostazja”, 9.09.2014. Wyborcza.pl, accessed on: 26.11.2019. Later, the Curia withdrew from the statement in brackets.

25 The availability of ethics classes has changed significantly over the last dozen years. In the 2006/2007 school year, only 285 schools organized ethics lessons. In 2014 (as of September 30), ethics was already taught in 2,471 schools. Rzecznik Praw Obywatelskich, Dostepność lekcji religii wyznań mniejszościowych i lekcji etyki w ramach systemu edukacji szkolnej-analiza i zalecenia, Warszawa 2015, p. 35. In the 2017/2018 school year, ethics classes were held by ca. 3300 schools. Suchecka, J., Rodzice wciąż musza walczyć o lekcje etyki "Zajęcia zaczynaja się o 7.15", 2.04.2018. Wyborcza.pl, accessed on: 28.11.2019. 
of the ECtHR highlighted that it was inappropriate for the religious education program to include the rites pertaining only to a single religion and/or be reduced to learning the prayers, psalms, memorizing religious texts, rituals of a single religious group. ${ }^{26}$ Also, the Polish literature expresses the view that the basis of assessment of religion education should be the student's knowledge as well as his/her diligence and activity, though it should not include the student's participation in religious practices. ${ }^{27}$

The reality is different: the basis for the assessment of "religion classes" very often involves the quantity and quality of the student's religious practices, such as participation in certain religious services. Religious education classes are not comparable with the lessons of other subjects - they are not primarily concerned with the transfer of scientific knowledge, such as mathematics, chemistry or history classes. They do not resemble religious studies but are of catechetical nature. ${ }^{28}$ They are used for shaping the student's religious training and social attitudes in accordance with the doctrinal principles of a given religious organization, leading to the assimilation of "the truths of faith" and the formation of the habit of participating in ceremonial activities. It is doubtful whether, from this viewpoint, the instruction at a public school should be more effective than one held outside school, that is, at an education facility of a religious association. It is unacceptable for the grade in religious education to be seen as equal with the assessment of the success in the field of religious indoctrination of the students. Above all, it should by no means be treated as a means of assessment of the success in shaping the student's negative attitude towards "infidels", atheists, agnostics, or any students not participating in the instruction of the dominant religion. To protect the latter students against religiously motivated harassment from some teachers and some of the "majority" part of the peer environment is an inalienable responsibility of public school authorities, as well as government and local authorities.

26 ECtHR, Folgero and Others v. Norway, Application no.15472/02, the Grand Chamber, 29 June 2007, par. 94; ECtHR, Hasan and Eylem Zengin v. Turkey, Application no. 1448, 9 January 2008, par. 60 and 62; Sobczak,W., op. cit., p. 446.

27 Mezglewski, A., Nauczanie religii w publicznych przedszkolach $i$ szkołach, in: Mezglewski, A., Misztal, H., Stanisz, P., Prawo wyznaniowe, Warszawa 2011, p. 176.

28 Brzozowski, W., Bezstronność światopogladowa władz publicznych $w$ Konstytucji RP, Warszawa 2011, p. 37. 
Thus, it is crucial to ask the following question: can the government interfere with the content of the curriculum and the method of religious instruction at a public school? In the light of the judicature of the ECtHR, a positive response does not raise any doubt. According to the Court, school education should take into account the cultural and religious diversity of societies of Europe, and because teaching is a holistic process - religious issues cannot be excluded from its framework. Religious elements are also present in the overall teaching content in public schools, which means that parents, regardless of their religious or philosophical beliefs, are not entitled to demand that their children were deprived of contact with any of them, or specifically with some of the philosophical or religious views, for example during the lessons of history, literature, or art history. The content of school programs must, however, be presented in an objective, critical and pluralist manner, allowing students to shape the "critical approach in the matters of religion," and "in a peaceful atmosphere, free from improper proselytism". Any indoctrination without any regard to the parents' convictions is prohibited. The right of parents to the education and teaching of their children in conformity with their religious and philosophical convictions (Article 2 of Protocol No. 1 to the European Convention for the Protection of Human Rights and Fundamental Freedoms) is related to the fundamental right to education and should be read in conjunction with Articles 8, 9 and 10 of that Convention, and, therefore, with the right of every person "to respect for private and family life", to "freedom of thought, conscience and religion" as well as to "freedom of receiving and imparting information and ideas". According to the ECtHR, there are no obstacles for the public school curriculum to include separate classes in religion or about religion. However, they must respect the prohibition of indoctrination, which applies to both the content taught, and the organizational location of the subject. ${ }^{29}$ In several rulings, the Tribunal expressed the view that whenever the state introduces religious education to the school program, regardless of the possibility of obtaining exemption from such lessons, parents of attendees may expect this subject to be taught in a way that meets the criteria of objectivity and pluralism, respecting their religious and philosophical views. ${ }^{30}$

29 ECtHR, Kjeldsen, Busk Madsen and Petersen v. Denmark, Application no. 5095/71; 5920/72; 5926/72, 7 December 1976.

30 ECtHR, Hasan and Eylem Zengin v. Turkey, Application no. 1448/04; ECtHR, Mansur Yalcin and Others v. Turkey, Application no. 21163/11, 16 September 2014, par. 77; ECtHR, Izzettin Dogan and Others v. Turkey, Application no. 62649/10, 26 April 2016, par. 129. 
Binding regulations and actions undertaken by education authorities in Poland are markedly inconsistent with the ECtHR jurisprudence mentioned above. Public authorities and school management have not been awarded sufficient legal means and, most probably, are not quite willing to respond accordingly to the situation when indoctrination during religion classes is common rather than exceptional. The primary reason for this situation is the Concordat. Article 12 Part 2 thereof reads: "Catholic religion education curriculum, as well as appropriate textbooks shall be designed by church authorities and shall be presented to competent state authorities for informational purposes". The authors of the commentary to the Concordat (the issue of which was agreed upon by the Metropolitan Curia for Warsaw) are of the opinion that the statement quoted above gives church authorities the sole right to design the Catholic religion education curricula and textbooks and, at the same time, it repeals the statement included in the act on the education system which states that the Minister of National Education selects curricula and school textbooks which shall be certified for use in public schools. They also claim that such a procedure results from the fact that the state respects the church autonomy in designing and selecting curricula and textbooks used for teaching the Catholic religion. Due to the fact that religion is taught in public schools and kindergartens, curricula and textbooks should be familiar to the competent state authorities. However, any state interference in teaching truths of the faith would clearly contradict the rule of independence and autonomy of the state and the Church within their respective spheres of activity, referred to in Article 1 of the Concordat.

The Authors of the abovementioned commentary also claim that it is guaranteed that "the Church cares about the content of faith testimony". The regulations referred to in Article 12(3) and (4) of the Concordat assure that the teachers of religion are dependent on the church regulations and orders, in all matters which refer to "teaching religion" (religious instruction). Moreover, they have to obtain a certificate (missio canonica) awarded by a diocesan bishop, which confirms their allegiance to the Catholic doctrine and allows them to teach religion. Thereby, the Church has the possibility to decide on particular catechists (religious instructors) to be employed in public schools. This is supposed to protect the Church-bound identity within the scope of truths of the faith which are passed on, as well as a Catholic morality. According to the Authors: "The Church does not interfere in teaching other subjects or in any other issues which belong to the sphere of competence of 
the public education system, whereas the state does not teach the rules and truths of the faith. The autonomy of these two spheres is so strongly adhered to that it is also coherent with the rule of separating the state from the Church". ${ }^{31}$ However, I would not agree with this statement. Public authorities are not able to act effectively in situations where the Church interferes in teaching school subjects other than religion. On the other hand, they are not able to influence religious education curricula, even if religion classes included elements of indoctrination, promoted aversion to other denominations or conveyed messages which were strongly contradictory to information presented during classes in other school subjects (for example to the current research results in biology, medicine or history). ${ }^{32}$ They are, however, to finance religious education from public funds. ${ }^{33}$

7. The special privileges of the Catholic Church (visible in common religious instruction in public schools), which mainly result from the Concordat, are usually not granted to the representatives of other religions whose relations with the state are regulated by individual acts, and the Act on the freedom of conscience and religion. Breaking the constitutional rule concerning equal rights for different religious associations, referred to in Article 25 (1) of the Constitution, cannot be justified in this case. Nevertheless, the Constitutional Tribunal justifies it either by the wrong law interpretation, i.e. it claims that Article 25 (4) of the Constitution which legitimises the concordat shall be deemed lex specialis and, therefore, shall exclude the equal rights obligation - or by emphasizing the dominant position of the Catholic Church in society in terms of the number of followers. ${ }^{34}$

Teaching religious education in public schools provided by other religious associations which represent any "minority" would face significant legal and organizational obstacles, mostly because schools have the right and are obliged

31 Góralski, W., Pieńdyk, A., op. cit., pp. 39-41.

32 Polish Bishops' Conference, Core curriculum for the catechesis of the Catholic Church in Poland, Document adopted during the 379 Plenary Meeting of the Polish Bishops' Conference on June 8, 2018. This document was criticized by liberal circles, including Piotr Pacewicz in: Kościót na terenie świeckiej szkoty, 22.04.2019. OKO.press, accessed on: 28.11.2019.

33 Cf. Pacewicz, P., MEN: nauczanie religii kosztowało w 2018 roku 1,48 mld. OKO.press: katecheta zarabia średnio 4960 zt, 22.04.2019. oko.press, https://oko.press/men-nauczanie -religii-kosztowalo-w-2018-r-148-mld-oko-press-katecheta-zarabia-srednio-4960-zl/, accessed on: 24.04.2019. According to the Catholic Upbringing Commission of the Polish Bishops' Conference for the 2017/2018 school year, a total of 31,353 catechists (religious instructors) conveyed classes at Polish schools.

34 Brzozowski, W., Glosa do wyroku Trybunatu Konstytucyjnego z dnia 2 grudnia 2009 r., U 10/07, "Przegląd Sejmowy" 2010, No.4; Brzozowski, W., Bezstronność..., p. 219. 
to provide lessons of religion for a given denomination only if there are at least seven students of this denomination in a single class or group of students. For smaller groups, religion classes in school should be organised in a mixed class group, or in a group comprised of students from different schools or in a facility outside school, which in fact means outside the public school. The aforementioned quantity limits have been set illegally. ${ }^{35}$ They are not aligned with constitutional rules on equal treatment of all students by public authorities since they create special privileges for the followers of the dominant religion in terms of quantity, who can be taught religion in schools. They also provoke harassment towards students who are either members of other religious groups or who are confessionless. Furthermore, the limits provoke monopolization of the Catholic Church in teaching religion in public schools.

Problems related to restrictions of access to instruction in minority religions (as well as ethics classes), and detailed recommendations for actions that would allow these restrictions to be eliminated were presented in the report of the Commissioner for Human Rights to the Minister of National Education in 2015, titled "Availability of minority religious education and ethics lessons as part of the school education system. Analysis and recommendations", as well as in subsequent speeches from 2016 and 2018. In the last of these speeches, the Commissioner expressed a view that "any barriers to access to minority religious education or ethics classes, or unequal treatment of students not attending religion classes organized by the school, are symptoms of discrimination on the grounds of religion and worldview in the area of education." Among the remedies indicated in his speech was the postulate to amend the Regulation on the conditions and method of organizing religious education in public pre-schools and schools of 14 April 1992, imposing an obligation on school heads to inform parents and students about the possibilities and principles of organizing religious education or ethics classes. This can lead to increased awareness of the existence of such entitlement in children and families from minority religious groups (ones with a minor number of followers in a given area). The Commissioner pointed out the need to remove organizational restrictions, including the ones associated with difficult commuting, long waiting times for classes, or the need to choose between religion or ethics classes and other extracurricular activities, as well as the need to inform parents and students that it

35 Directive of the Minister of National Education of 14 April 1992 on the conditions and ways of organizing religious education lessons in public schools and pre-school, Dz. U. (Journal of Laws) of 1992, No. 36, item 155, as amended) was issued without statutory authorization. 
is possible to attend religious education and ethics concurrently. ${ }^{36}$

8. In Poland, the right to be taught religion in public schools is no longer (to such a large extent) associated with the right to be taught in general, which is due to the fact that religious instruction has become, to a large extent, an indoctrination tool. It also ceased to bear a clear relation to the core principle of the freedom of conscience and religion since all too often religion is taught in a way which clearly contradicts this freedom. However, undoubtedly, the legal regulations concerning religious education in public schools provide organizational and financial support to the public authorities for implementing religious missions of religious associations, with the special influence of strengthening the social impact of the Catholic Church. However, this support is not fully effective, since the tendency of students (parents of students) to resign from religion lessons has been increasing for several years.

In this situation, more and more doubts are raised by legal solutions according to which religious education should be treated as one of several optional subjects, equal to other subjects in the school curriculum, with general grading principles applied. ${ }^{37}$ It is, however, an utter misunderstanding to assume (de lege lata) religious education to be a compulsory subject. ${ }^{38}$ It is neither legally applicable, nor legitimate to include grades from a religion/ethics class in an end-of-year school certificate, as this incorrectly suggests the joint responsibility of public school authorities for the correctness of these grades and the correctness of the content and methods of teaching religious education classes, which, in fact, could not be influenced by the school authorities by any way. Moreover, the lack of a grade in the space provided for religion class grade (i.e. a hyphen instead of a numeric mark) stigmatizes a student who does not attend religion classes, because ethics classes are not held in the vast majority of Polish schools. In the Grzelak v. Poland case, the ECtHR decided that the lack of a mark in the space called "religion/ethics" in subsequent school certificates signifies a breach of Article 14 in connection with Article 9 of the European Convention for the Protection of Human Rights and Fundamental Freedoms. ${ }^{39}$ Obviously, this also

36 Speech of the Commissioner for Human Rights to the Minister of National Education of 20.09.2018. Letter No. XI.5601.4.2016.JS.

37 Act of 7 September 1991 on the education system, Dz. U. (Journal of Laws) of 2019, item 1481 , as amended.

38 The Catholic Upbringing Commission of the Polish Bishops' Conference has expressed a view that religious education is an elective class, which becomes compulsory if declared by the parents or major students.

39 ECtHR, Grzelak v. Poland, Application no. 7710/02, 22 November 2010; Cf. Brzozowski, W., Bezstronność..., p. 220, Sobczak, W., op. cit., p. 447. 
entails a breach of Article 32 and Article 53(7) of the Constitution (unequal treatment by public authorities and breaking the confidentiality of one's religious convictions).

Therefore, it is not possible to agree with the opinion of the Constitutional Tribunal which claims that the regulations that justify awarding end-of-year grades in religion classes and including them in the so-called grade average are consistent with the Constitution and are not contradictory to the act on the guarantees of the freedom of conscience and religion. ${ }^{40}$ These regulations allow for legal privileges for students who attend religion classes. These classes help in student's efforts to be accepted into certain post-primary level schools, where admission (and scholarships) is granted on the basis of a grade average. Usually, it is fairly easy to be awarded a high grade in religion classes - and such a grade is not always granted for educational excellence, but for example for the account of systematic taking of Holy Communion or attending morning Advent masses. The students who are awarded such high grades have better chances to be admitted to prestigious post-primary level schools or be awarded a scholarship. This proves that the abovementioned regulations contravene constitutional regulations concerning equality within the legal system and the right to equal treatment by the public authorities (Article 32(1) of the Constitution). They are also inconsistent with the rules of good, rational educational system.

9. The standards shaping the freedom of conscience and religion across education established by the Constitutional Tribunal of Poland differ significantly from the standards established in the case-law of the HRC and the ECtHR. Furthermore, these standards are only seemingly consistent with the rule of impartiality of public authorities. They lead to a situation of tolerance for violating this principle repeatedly in cases related to religious education in public schools, either openly or secretly. Such a situation is favoured by the legislation which is marked by significant defects, as well as the biased practice of educational administration in religious matters. What is glaringly visible in this context is the inability of state and local government institutions (who are obliged to supervise these matters) to take a proper course of action.

The neutrality of public authorities (Article 25(2) of the Constitution) is understood, as mentioned by T.J. Zieliński, as indifference to the actions under-

40 Directive of the Minister of National Education of 13 July 2007 amending the directive on the conditions and the ways of assessment, classifying and promoting students and conducting tests and examinations in Public schools, Dz. U. (Journal of Laws) of 2007, No. 130, item 906; Constitutional Tribunal ruling of 2 December 2009, U 10/07, OTK-A 2009, No. 11, item 1630. 
taken by the entity who intends to assume domination over the sphere which should be governed by the state and which should not be claimed by any particular group. The public educational system, from which the state withdrew to a significant extent, is such a vulnerable sphere..$^{41}$ This situation should change. In particular, there is a need for a new legislative vision of a role and tasks of the state in terms of protecting the freedom of conscience and religion in the educational activity of public schools. This vision should be strongly coherent with general and European standards and it should assure philosophical neutrality of public schools, even if religious education is continued in them.

\section{Literature}

Brzozowski, W., Bezstronność światopogladowa władz publicznych w Konstytucji RP, Warszawa 2011.

Brzozowski, W., Glosa do wyroku Trybunału Konstytucyjnego z dnia 2 grudnia 2009 r., U 10/07, "Przegląd Sejmowy" 2010, No. 4.

Florczak-Wątor, M., Art.53 [Wolność sumienia i wyznania], in: Tuleja, P. (ed.), Konstytucja Rzeczypospolitej Polskiej Komentarz, Warszawa 2019.

Góralski, W., Pieńdyk, A., Zasada niezależności i autonomii państwa i Kościoła w konkordacie polskim z 1993 r., Warszawa 2007.

Kasiński, M., Ochrona wolności sumienia i wyznania, in: Duniewska, Z. (ed.) et al., Prawo administracyjne materialne, Warszawa 2019.

Mezglewski, A., Nauczanie religii w publicznych przedszkolach i szkołach, in: Mezglewski, A., Misztal, H., Stanisz, P., Prawo wyznaniowe, Warszawa 2011.

Nowicki, M.A., Wokót Konwencji Europejskiej. Komentarz do Europejskiej Konwencji Praw Czlowieka, Warszawa 2017.

Pietrzak, M., Państwo laickie, "Przegląd Humanistyczny" 1990, No. 8-9, reprint: Pietrzak, M., Demokratyczne, świeckie państwo prawne, Warszawa 1999.

Sobczak, W., Wolność myśli, sumienia i religii. Poszukiwanie standardu europejskiego, Torun 2013.

Statement of the EPC: Religious education not is an optional subject. Classes can take place in the middle of the school day, 18.03.2019, Gazeta.pl.

${ }^{41}$ Zieliński, T., Zakaz indoktrynacji światopogladowej w szkolnictwie wedtug wyroku Lautsi przeciwko Włochom, in: Wieruszewski, R., Wyrzykowski, M., Kondratiewa-Bryzik, L. (eds.), Prawne granice wolności sumienia i wyznania, Warszawa 2012, pp. 73-74. 
Suchecka, J., Kuria straszy rodziców. Wypisałeś dziecko z religii? "To pisemna apostazja”, 9.09.2014, Wyborcza.pl.

Wieruszewski, R., Nauczanie religii w szkołach publicznych oraz finansowanie szkót religijnych w świetle orzecznictwa Komitetu Praw Człowieka ONZ, in: Wieruszewski, R., Wyrzykowski, M., Kondratiewa-Bryzik, L. (eds.), Prawne granice wolności sumienia $i$ wyznania, Warszawa 2012.

Zieliński, T., Zakaz indoktrynacji światopogladowej w szkolnictwie wedhug wyroku Lautsi przeciwko Włochom, in: Wieruszewski, R., Wyrzykowski, M., Kondratiewa-Bryzik, L. (eds.), Prawne granice wolności sumienia i wyznania, Warszawa 2012.

\section{Legislation}

Act of 10 June 2015 on specific conditions and grading, classifying and promotion schemes for students and course participants at public schools, Dz. U. (Journal of Laws) of 2019, item 372.

Act of 17 May 1989 on guarantees of freedom of conscience and belief, Dz. U. (Journal of Laws) of 2017, item 1153.

Act of 17 May 1989 on the relations of the State and the Catholic Church in the Republic of Poland, Dz. U. (Journal of Laws) of 2018, item 380, as amended.

Act of 2 April 1997 Constitution of the Republic of Poland, Dz. U. (Journal of Laws) of 1997 No. 78, item 483, as amended.

Act of 20 November 1989 on ratifying the UN Convention on the Rights of the Child, Dz. U. (Journal of Laws) of 1991 No.120, item 526, as amended).

Act of 28 July 1993 Concordat between the Holy See and Poland, Dz. U. (Journal of Laws) of 1998 No. 51, item 318.

Act of 7 September 1991 on the education system, Dz. U. (Journal of Laws) of 2019, item 1481 , as amended.

Act of 7 September 1991 on the education system, Dz. U. (Journal of Laws) of 2019, item 1481 , as amended.

Constitutional Tribunal ruling of 2 December 2009, U 10/07, OTK-A 2009 No. 11, item 1630.

Council of Europe, European Convention for the Protection of Human Rights and Fundamental Freedoms, as amended by Protocols Nos. 11 and 14, 4 November 1950, ETS 5.

Directive of the Minister of National Education of 13 July 2007 amending the directive on the conditions and the ways of assessment, classifying and promoting students and conducting tests and examinations in Public schools, Dz. U. (Journal of Laws) of 2007 No.130, item 906. 
Directive of the Minister of National Education of 14 April 1992 on the conditions and ways of organizing religious education lessons in public schools and pre-school, Dz.U. (Journal of Laws) of 1992 No. 36, item 155, as amended.

European Union, Charter of Fundamental Rights of the European Union, OJ C 326, 26.10.2012, p. 391-407.

Organization for Security and Co-operation in Europe (OSCE), Conference on Security and Co-operation in Europe (CSCE): Final Act of Helsinki, 1 August 1975.

Regulation of the Ministry of Education of 14 April 1992 on conditions and ways of organizing religious education in public pre-schools and schools, Dz. U. (Journal of Laws) of 1992 No. 36, item 155.

UN General Assembly, International Covenant on Civil and Political Rights, 16 December 1966, United Nations, Treaty Series, vol. 999, p. 171.

UN General Assembly, International Covenant on Economic, Social and Cultural Rights, 16 December 1966, United Nations, Treaty Series, vol. 993, p. 3.

\section{Polish Commissioner for Human Rights}

Polish Commissioner for Human Rights, Speech to the Minister of National Education of 20/9/2018. Letter No. XI.5601.4.2016.JS.

Polish Commissioner for Human Rights, Statement of 15 November 2013, reference number RPO/601727/08/1/104122. http://www.sprawy-generalne.brpo.gov.pl.

\section{Judicial decisions}

ECtHR, Angeleni v. Sweden, Application no. 1049/83, 3 December 1986.

ECtHR, Bernard v. Luxembourg, Application no. 17187/90, 8 September 1993.

ECtHR, C.J., J.J., E.J. v. Poland, Application no. 23380/94, 16 January 1996.

ECtHR, Folgero and Others v. Norway, Application no.15472/02, the Grand Chamber, 29 June 2007.

ECtHR, Grzelak v. Poland, Application no. 7710/02, 22 November 2010.

ECtHR, Hasan and Eylem Zengin v. Turkey, Application no. 1448/04, 7 October 2007.

ECtHR, Hasan and Eylem Zengin v. Turkey, Application no. 1448, 9 January 2008.

ECtHR, Izzettin Dogan and Others v. Turkey, Application no. 62649/10, 26 April 2016.

ECtHR, Kjeldsen, Busk Madsen and Petersen v. Denmark, Application no. 5095/71; 5920/72; 5926/72, 7 December 1976. 
ECtHR, Lautsi and others v. Italy, Application no. 30814/06, Grand Chamber, 18 March 2011.

ECtHR, Mansur Yalcin and Others v. Turkey, Application no. 21163/11, 16 September 2014.

\section{Internet sources}

Nauczanie religii $w$ polskiej szkole, 10.01.2019, https://ekai.pl/nauczanie-religii-w-polskiejszkole-2.

Pacewicz, P., MEN: nauczanie religii kosztowato w 2018 roku 1,48 mld. OKO.press: katecheta zarabia średnio 4960 zt, 22.04.2019, https://oko.press/men-nauczanie-religii-kosztowalo-w-2018-r-148-mld-oko-press-katecheta-zarabia-srednio-4960-zl. 